\title{
In vitro Inhibition of Pectolytic Enzymes of Erwinia chrysanthemi by Combined Application of Pseudomonas fluorescens and Bacillus subtilis on Aloe vera
}

\author{
M. Syamala* and C. Ciba \\ Department of Plant Pathology and Department of Horticulture, Agricultural College and \\ Research Institute, Tamil Nadu Agricultural University, Coimbatore-641003, Tamil Nadu, India \\ *Corresponding author
}

\begin{tabular}{|c|c|}
\hline & A B S T R A C T \\
\hline & $\begin{array}{l}\text { In an attempt to develop biocontrol system for management of soft rot in Aloe vera, } \\
\text { Pseudomonas fluorescens and Bacillus subtilis were evaluated for their antagonistic }\end{array}$ \\
\hline Keywords & $\begin{array}{l}\text { activity against Erwinia chrysanthemi in vitro. Soft rot diseases caused by the Erwinia } \\
\text { chrysanthemi lead to significant yield losses of crops. Experiments were conducted on the }\end{array}$ \\
\hline $\begin{array}{l}\text { Pseudomonas } \\
\text { fluorescens, } \\
\text { Bacillus subtilis. }\end{array}$ & $\begin{array}{l}\text { effect of culture filtrates of combined application of }(\mathrm{Pf} 32+\mathrm{Pf} 45+\mathrm{Bs} 5) \text { on the in vitro } \\
\text { inhibition of pectinolytic enzymes of Erwinia chrysanthemi. The activity of pectate lyase } \\
\text { activity, pectin methyl esterase, polygalacturonase, pectin trans eliminase activity }\end{array}$ \\
\hline Article Info & $\begin{array}{l}\text { produced by Erwinia chrysanthemi was higher, when compared to control. Maximum } \\
\text { inhibition of above pectinolytic enzymes (PME, PG and PTE) was shown by Pseudomonas }\end{array}$ \\
\hline $\begin{array}{l}\text { Accepted: } \\
07 \text { October } 2017 \\
\text { Available Online: } \\
10 \text { December } 2017\end{array}$ & $\begin{array}{l}\text { fluorescence treatment was followed Bacillus subtilis. Of all the treatments, Pseudomonas } \\
\text { fluorescence treatment showed higher rate of inhibition of Pectinolytic enzymes of } \\
\text { Erwinia chrysanthemi. This study indicates that combined application of }(\operatorname{Pf} 32+\mathrm{Pf} 45 \\
+ \text { Bs5) is the best biocontrol agent in the inhibition of Erwinia chrysanthemi causing soft }\end{array}$ \\
\hline & $\begin{array}{l}\text { rot of Aloe vera. The enzyme activity of inoculated aloe plants increased from the two day } \\
\text { till the six DAI and slowly declined thereafter in all the } 15 \text { isolates. }\end{array}$ \\
\hline
\end{tabular}

\section{Introduction}

Aloe vera (L) Burm is one of the medicinal plants widely used throughout the world (Sofowora, 1984). It is a well-known medicinal plant of India and is one of the world most demanded crop. It is naturalized throughout the country, more common along the west coast (Robert and Hentry, 2004). Plants of the genus Aloe vera belong to old world and are indigenous to Eastern and Southern Africa. The plant is found in the tropics and introduced to India for ornamental and medicinal purpose. Aloe genus consists of about 325 species all of which grow in rosette shape (Anselm, 2004). It has been established that the inner gel of the leaf contains most of its beneficial part (Swaminathan and Kochhar, 1992). Aloe vera has many medicinal and cosmetic usages and hence has growing demand in the market. The plant is a rich source of amino acids and enzymes (Blumenthal and Mark, 2000). The gel of the leaf of Aloe vera contains 96 per cent of water and the remaining different elements such as vitamins and minerals (Tyler, 1994). The 
plant also contains essential oil components (Davis et al., 2000). It is referred to as miracle plant for its numerous uses, particularly in the area of man's health (Hect, 1981). It is estimated that the global trade in Aloe vera raw material and derived products is worth about \$ 110 million. Aloe vera is cultivated in 380 ha in Texas, Florida and Southern California. Southern California has become the largest grower in the world by growing 250,000 Aloe vera plants on 70 acres.

Diseases and nematodes cause considerable yield losses. Among these bacterial soft rot of Aloe vera caused by Erwinia chrysanthemi is economically important as it causes yield loss upto 80 per cent. The degradation of complex polymers of carbohydrates to simple one is brought about by the production of various pectic and pectolylic enzymes produced by Erwinia chrysanthemi Pectolytic microorganisms or cell free pectic enzymes are responsible for tissue maceration was observed. The present investigation revealed the production of polygalacturanase, pectin methyl esterase, pectin trans eliminase and pectate lyase in the aloe plants inoculated with E. chrysanthemi.

Sendhilvel (2000) reported that pectolytic enzymes, viz., polygalacturonase, pectin methyl esterase, pectin trans eliminase and pectate lyase were produced by the soft rot bacterium E. carotovora var. carotovora and its rate of production was higher in the highly susceptible onion. Parthiban (2004) observed the increased activity of pectolytic enzymes, viz., Polygalacturonase, pectin methyl esterase, pectin-transeliminase and pectate lyase in carrot roots infected with various post harvest pathogens. Rajkumar (2006) observed increased activity of pectolytic enzymes, viz., Polygalacturonase, pectin methyl esterase, pectin-transeliminase and pectate lyase in banana rhizomes infected with soft rot pathogen E. carotovora subsp. carotovora.

\section{Materials and Methods}

\section{Pathophysiology}

The bio-chemical changes taking place in the leaves at one, two, three, four and five days after inoculation of $E$. chrysanthemi was studied as described below. Leaf without pathogen inoculation was kept as control.

\section{Estimation of enzymes involved in pathogenesis}

Erwinia culture cells was collected from each isolates by centrifugation at $1200 \mathrm{r} /$ minute and the supernatants were sterilized by filtration through a 0.22 (pore size) milliphore filter. For extracellular enzymes, supernatant was collected in early stationary phase because the extracellular enzymes are produced in a growth phase dependent manner. All the supernatants were from at $20^{\circ} \mathrm{C}$ in aliquots were maintained until required for further experiments (Pirhomen et al., 1993).

\section{Assay of Pectate Lyase (PL) activity}

PL activity was determined by monitoring the formation of $\mathrm{C}_{4}$ and $\mathrm{C}_{5}$ unsaturated products spectrophotometrically at $235 \mathrm{~nm}$ (Laurent et al., 2000). Five hundred $\mu 1$ of $0.1 \mathrm{M}$ TrisHC1 (pH 9) buffer containing $0.5 \mathrm{mM} \mathrm{CaCl} 2$ was rapidly mixed in a $1.5 \mathrm{ml}$ cuvette with $370 \mu \mathrm{l}$ of distilled water, $100 \mu \mathrm{l}$ of a polygalacturonic acid solution $(1 \% \mathrm{w} / \mathrm{v})$ in water, and $30 \mu \mathrm{l}$ of supernatant obtained by grinding infected aloe vera leaf tissue in a pestle and mortar using $0.1 \mathrm{M}$ Tris $\mathrm{HCl}(\mathrm{pH} 9)$ buffer. The reaction mixture was incubated at $30^{\circ} \mathrm{C}$. One unit was defined as the amount of enzyme which produced $1 \mu \mathrm{m}$ of unsaturated product. Activity was expressed in micromoles of unsaturated product liberated per minute per $\mathrm{ml}$ of supernatant and specific activity was expressed in $\mu \mathrm{m}$ of unsaturated 
product liberated per minute per $\mathrm{ml}$ of $\mathrm{OD}$ at $580 \mathrm{~nm}$.

\section{Assay of Pectin Methyl Esterase (PME) activity}

The enzyme activity was assayed as per the procedure given by Mahadevan and Sridhar (1982). Twenty $\mathrm{ml}$ of pectin solution was pipetted in a $50 \mathrm{ml}$ beaker and $\mathrm{pH}$ was adjusted to 7.0. Ten $\mathrm{ml}$ of the enzyme solution was then added and the $\mathrm{pH}$ was immediately adjusted to 7.0 by adding $1 \mathrm{~N}$ $\mathrm{NaOH}$. This was kept as zero time. At every 15 min the $\mathrm{pH}$ was checked and alkali was added from the burette when the $\mathrm{pH}$ falls below the reference point, while stirring. To adjust the $\mathrm{pH}, 0.02 \mathrm{~N} \mathrm{NaOH}$ was used and the volume of alkali consumed was noted at each interval. The enzyme activity was expressed as $\mu \mathrm{m}$ of hydrogen ion per min per $\mathrm{ml}$ of the enzyme preparation.

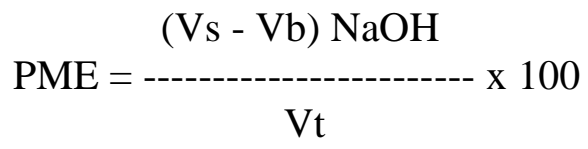

Where

$\mathrm{Vs}=$ Titre value

$\mathrm{Vb}=$ Volume of $1 \mathrm{~N}$ sodium hydroxide consumed to adjust the $\mathrm{pH}$ to 7.0

$\mathrm{V}=$ Volume of incubation mixture $(\mathrm{ml})$

$\mathrm{t}=$ Time period $($ minute $)$

Assay of Pectin Trans Eliminase (PTE) activity

PTE activity was estimated by the viscometric method described by Mahadevan and Sridhar (1982). Four $\mathrm{ml}$ of the substrate and one $\mathrm{ml}$ of the enzyme were pipetted into the viscometer. The loss in viscosity of the pectin solution was determined by using of Vinsell Viscometer of size 300. The activity was expressed as per cent reduction in viscosity.

$$
\mathrm{V}=\frac{\mathrm{T}_{0}-\mathrm{T}}{\mathrm{T}_{\mathrm{o}}-\mathrm{T}_{\mathrm{H} 2 \mathrm{O}}}
$$

Where

$\mathrm{V}$ - Per cent loss in viscosity

$\mathrm{T}_{\mathrm{o}}$ - Flow time in seconds at zero time

$\mathrm{T}$ - Flow time of reaction mixture at time $\mathrm{T}$

$\mathrm{T}_{\mathrm{H} 2 \mathrm{O}}$ - Flow time of distilled water

\section{Assay of Polygalacturonase (PG) activity}

The activity of PG was assayed as per the method described by Mahadevan and Sridhar (1982). One $\mathrm{g}$ of tissue was transferred to a wearing blender and five $\mathrm{ml}$ of $0.1 \mathrm{M}$ chilled phosphate buffer ( $\mathrm{pH}$ 6.6) was added. The material was blended for five min, filtered through two layers of cheese cloth and centrifuged at $2000 \mathrm{rpm}$ for $30 \mathrm{~min}$ at $4^{\circ} \mathrm{C}$. The supernatant was decanted and the clear extract was taken as enzyme source. Four ml of the substrate, one $\mathrm{ml}$ of acetate buffer $(\mathrm{pH}$ 5.2) and two ml of enzyme source were taken in a viscometer and the contents were mixed gently by drawing air rapidly through the large arm of the viscometer by suction. The efflux time of the mixture was determined by suction through small arm (zero time). The efflux time of the mixture after 30 min was measured. From this, the enzyme activity was calculated as per cent reduction in viscosity of the substrate from the following formula.

$$
\mathrm{V}=\frac{\mathrm{T}_{0}-\mathrm{T}}{\mathrm{T}_{\mathrm{O}}-\mathrm{T}_{\mathrm{H} 2 \mathrm{O}}}
$$

Where

$\mathrm{T}_{\mathrm{o}}$ - Flow time in seconds at zero time 
$\mathrm{T}$ - Flow time of reaction mixture at time $\mathrm{T}$

$\mathrm{T}_{\mathrm{H} 2 \mathrm{O}}$ - Flow time of distilled water.

\section{Estimation of sugars}

One hundred $\mathrm{mg}$ of representative inoculated plant sample was homogenized in five $\mathrm{ml}$ of 80 per cent ethanol. The homogenate was centrifuged at $1000 \mathrm{rpm}$ for $10 \mathrm{~min}$ and used for the estimation of total sugars and nonreducing sugars.

\section{Total sugar}

Total sugar content was estimated by anthrone method (Hedge and Hofrieter, 1962). Two hundred microlitre of ethanol extract was evaporated using a water bath at $80^{\circ} \mathrm{C}$ and one $\mathrm{ml}$ water was added to dissolve the sugars. Anthrone reagent was prepared by dissolving $200 \mathrm{mg}$ anthrone in $10 \mathrm{ml}$ ice cold 95 per cent sulphuric acid just before use. Four $\mathrm{ml}$ of anthrone reagent were added and the reaction mixture was heated for eight min in a boiling water bath and cooled rapidly. The absorbance of the green coloured solution was measured at $630 \mathrm{~nm}$ using spectrophotometer. D-glucose was used as standard. The total sugar content was expressed in terms of per cent on fresh weight basis.

\section{Reducing sugar}

The method of Somogyi (1952) was followed to estimate the reducing sugar content. Two hundred microlitre of ethanol extract was evaporated using water bath. The residue was dissolved in two $\mathrm{ml}$ of distilled water. One $\mathrm{ml}$ of alkaline copper tartarate was added and the reaction mixture was heated for 10 minutes in a boiling water bath and cooled rapidly. Alkaline copper tartarate was prepared by dissolving $2.5 \mathrm{~g}$ anhydrous sodium carbonate, $2.0 \mathrm{~g}$ sodium bicarbonate, $2.5 \mathrm{~g}$ sodium potassium tartarate and $20 \mathrm{~g}$ anhydrous sodium sulphate in $80 \mathrm{ml}$ of water and finally made upto $100 \mathrm{ml}$.

The reaction mixture was incubated for 10 minutes at room temperature. The intensity of blue colour was measured at $620 \mathrm{~nm}$ using spectrophotometer. D-glucose was used as a standard. The reducing sugar content was expressed in terms of per cent on fresh weight basis.

\section{Non-reducing sugar}

The difference between total sugar and reducing sugar corresponds to the nonreducing sugar.

\section{The treatment details are as follows}

T1- P. fluorescens - $32(1 \mathrm{~kg} / \mathrm{ha})$

T2 - P. fluorescens $-45(1 \mathrm{~kg} / \mathrm{ha})$

$\mathrm{T} 3$ - Bacillus subtilis $-5(1 \mathrm{~kg} / \mathrm{ha})$

$\mathrm{T} 4-\mathrm{T} 1+\mathrm{T} 2 \quad(1 \mathrm{~kg} / \mathrm{ha})$

$\mathrm{T} 5-\mathrm{T} 1+\mathrm{T} 3 \quad(1 \mathrm{~kg} / \mathrm{ha})$

$\mathrm{T} 6-\mathrm{T} 2+\mathrm{T} 3 \quad(1 \mathrm{~kg} / \mathrm{ha})$

$\mathrm{T} 7-\mathrm{T} 1+\mathrm{T} 2+\mathrm{T} 3 \quad$ (1kg/ha)

T8-Zimmu (Allium sp $10 \%$ leaf extract $1 \mathrm{~kg} / \mathrm{ha}$ )

T9-Neem oil (3\%)

T9- Mahua oil (3\%)

T10-NSKE (5\%)

T11-Streptomycin sulphate (300g)

T12 - Untreated control

\section{Results and Discussion}

Pectate lyase activity (PL) by different isolates of E. chrysanthemi in Aloe vera

The results revealed that the Pectate lyase activity of all the aloe plants inoculated increased from one minute to three min time interval and after words slowly declined in the case of all isolates. The enzyme activity was the maximum in $\mathrm{I}_{9}$ (Melur) isolate (OD 3.010) at three min of incubation as compared to the other isolates of $E$. chrysanthemi. The pectate 
lyase activity in three min ranged from 2.645 to 3.010OD. The least pectate lyase activity was observed in $\mathrm{I}_{2}$ (Tenkasi) (OD 2.645) (Table 1). The present study revealed increased pectate lyase activity in the Aloe vera plants inoculated with $\mathrm{I}_{9}$ (Melur) isolate which is the most virulent of all the 15 isolates which corroborated the findings of Raj kumar (2006) in respect of E. carotovora subsp. carotovora Mettupalayam isolate (most virulent).

Pectin Methyl Esterase (PME) by different isolates of $E$. chrysanthemi Aloe vera

All the 15 isolates of E. chrysanthemi were assessed for their ability to produce PME in Aloe vera. The accumulation of $\mathrm{PME}$ increased two days after inoculation (DAI) and attained a peak six days after inoculation and slowly declined thereafter in all the isolates. The PME activity six DAI ranged from 0.27 to $1.14 \mu$ mole hydrogen ion $\mathrm{min}^{-1}$ $\mathrm{ml}^{-1}$ in the isolates. Enhanced activity of PME was recorded in the leaves inoculated with $\mathrm{I}_{9}$ (Melur) isolate $(1.14 \mu$ mole hydrogen ion $\min ^{-1} \mathrm{ml}^{-1}$ ) six days after inoculation. The isolate $\mathrm{I}_{11}$ exhibited the least amount of PME activity $\left(0.28 \mu\right.$ mole hydrogen ion $\mathrm{min}^{-1}$ $\mathrm{ml}^{-1}$ ). The present study showed an enhanced activity of PME in the aloe leaves inoculated with the most virulent isolate. Similar observations made in carrot roots inoculated with Fusarium solani f. sp. radicicola by Abraham (1999) (Table 2).

Polygalacturanase (PG) activity of different isolates of $E$. chrysanthemi Aloe vera

The PG activity of inoculated aloe plants increased from the two day till the six DAI and slowly declined thereafter in all the 15 isolates. The isolate $\mathrm{I}_{9}$ (Melur) showed higher activity of Polygalacturonase $(40.30 \%$ in viscosity) on eight DAI as compared to the other isolates. The PG activity six DAI was ranged from 23.50 to 40.30 per cent reduction in viscosity. The PG activity was minimum (23.10\% reduction in viscosity) in the isolate $\mathrm{I}_{3}$ (kadambur) six DAI (Table 3). By the above studies, the most virulent isolate $\mathrm{I}_{9}$ showed the highest PG activity in the present study. The poly galacturonase activity of Erwinia carotovora subsp carotovora in carrot was documented by Parthiban (2003).

Pectin Trans Eliminase (PTE) by different isolates of $E$. chrysanthemi in Aloe vera

Assay for Pectin trans eliminase activity indicated that, there was no pectin trans eliminase activity in healthy plants. While Pectin trans eliminase of all the inoculated aloe plants increased from two DAI till the six DAI and thereafter slowly declined in all the isolates. The plants inoculated with $E$. chrysanthemi isolate $\mathrm{I}_{9}$ (Melur) showed higher activity of pectin trans eliminase (64.60\% reduction in viscosity) on six DAI (Table 4). The enzyme activity six DAI ranged from 39.70 to 64.60 (\% reduction in viscosity). The enzyme activity while it was least in the isolate $\mathrm{I}_{15}(39.70 \%$ reduction in viscosity) on six DAI (Table 4). Raj kumar (2006) also observed the same trend of increase in the activity of pectin trans eliminase in the banana rhizomes inoculated with $E$. carotovora subsp. carotovora.

Changes in content of total sugar in Aloe vera due to infection by different isolates of $E$. chrysanthemi

The results revealed increased total sugar cont ent in the plants inoculated with the bacterium even from two DAI. In respect of the isolates, it ranged from 33.33 to 47.47 per cent increase six DAI. It was observed that the total sugar content appreciably increased $(47.47 \%)$ Melur isolate $\left(\mathrm{I}_{9}\right)$ followed by Palamadu isolate 46.46. The total sugar content six DAI ranged from 13.20 to 14.60 per cent over control (Table 6). 
Table.1 Pectate lyase activity (PL) by different E. chrysanthemi isolates in Aloe vera

\begin{tabular}{|c|c|c|c|c|}
\hline \multirow{2}{*}{ Isolates } & \multicolumn{4}{|c|}{ OD value at $580 \mathrm{~nm}^{*}$} \\
\hline & $1 \mathrm{~min}$ & $2 \min$ & $3 \min$ & $4 \mathrm{~min}$ \\
\hline $\mathrm{I}_{1}$ & $2.604^{\mathrm{g}}$ & $2.724^{\mathrm{f}}$ & $2.808^{\mathrm{g}}$ & $2.687^{\mathrm{h}}$ \\
\hline $\mathrm{I}_{2}$ & $2.496^{\mathrm{m}}$ & $2.564^{\mathrm{m}}$ & $2.645^{1}$ & $2.504^{\circ}$ \\
\hline $\mathrm{I}_{3}$ & $2.549^{\mathrm{k}}$ & $2.655^{\mathrm{k}}$ & $2.741^{j}$ & $2.655^{\mathrm{j}}$ \\
\hline $\mathrm{I}_{4}$ & $2.688^{\mathrm{b}}$ & $2.769^{c}$ & $2.854^{\mathrm{c}}$ & $2.725^{\mathrm{c}}$ \\
\hline $\mathrm{I}_{5}$ & $2.613^{\mathrm{e}}$ & $2.716^{\mathrm{g}}$ & $2.825^{\mathrm{e}}$ & $2.714^{\mathrm{e}}$ \\
\hline $\mathrm{I}_{6}$ & $2.587^{1}$ & $2.691^{i}$ & $2.801^{\mathrm{h}}$ & $2.596^{\mathrm{m}}$ \\
\hline $\mathrm{I}_{7}$ & $2.609^{t}$ & $2.723^{\mathrm{f}}$ & $2.739^{k}$ & $2.634^{\mathrm{k}}$ \\
\hline $\mathrm{I}_{8}$ & $2.541^{1}$ & $2.652^{1}$ & $2.738^{\mathrm{k}}$ & $2.632^{1}$ \\
\hline $\mathrm{I}_{9}$ & $2.715^{\mathrm{a}}$ & $2.897^{\mathrm{a}}$ & $3.010^{\mathrm{a}}$ & $2.879^{\mathrm{a}}$ \\
\hline $\mathrm{I}_{10}$ & $2.689^{b}$ & $2.803^{\mathrm{b}}$ & $2.924^{\mathrm{b}}$ & $2.575^{\mathrm{n}}$ \\
\hline $\mathrm{I}_{11}$ & $2.626^{\mathrm{c}}$ & $2.713^{\mathrm{h}}$ & $2.802^{\mathrm{h}}$ & $2.754^{\mathrm{b}}$ \\
\hline $\mathrm{I}_{12}$ & $2.562^{j}$ & $2.689^{j}$ & $2.794^{i}$ & $2.671^{1}$ \\
\hline $\mathrm{I}_{13}$ & $2.613^{\mathrm{e}}$ & $2.738^{\mathrm{d}}$ & $2.826^{\mathrm{e}}$ & $2.703^{\mathrm{t}}$ \\
\hline $\mathrm{I}_{14}$ & $2.621^{\mathrm{d}}$ & $2.734^{\mathrm{e}}$ & $2.831^{\mathrm{d}}$ & $2.720^{\mathrm{d}}$ \\
\hline $\mathrm{I}_{15}$ & $2.597^{\mathrm{h}}$ & $2.715^{\mathrm{h}}$ & $2.813^{\mathrm{t}}$ & $2.699^{\mathrm{g}}$ \\
\hline Control & 0.006 & 0.009 & 0.008 & 0.008 \\
\hline
\end{tabular}

* Mean of three replications

In a column, means followed by common letters are not significantly different at 5\% level by DMRT

Table.2 Pectin Methyl/Esterase (PME) by different isolates of E. chrysanthemi in Aloe vera

\begin{tabular}{|c|c|c|c|c|}
\hline \multirow{3}{*}{ Isolates } & \multicolumn{4}{|c|}{ PME $\left(\mu\right.$ mole hydrogen ion $\left.\min ^{-1} \mathrm{ml}^{-1}\right)$} \\
\hline & \multicolumn{4}{|c|}{ Days after inoculation(DAI)* } \\
\hline & 2 & 4 & 6 & 8 \\
\hline $\mathrm{I}_{1}$ & $0.16^{\mathrm{d}}$ & $0.21^{\mathrm{e}}$ & $0.48^{\mathrm{d}}$ & $0.36^{\text {cd }}$ \\
\hline$I_{2}$ & $0.14^{\mathrm{T}}$ & $0.25^{\mathrm{d}}$ & $0.45^{\mathrm{g}}$ & $0.38^{\mathrm{b}}$ \\
\hline $\mathrm{I}_{3}$ & $0.07^{\mathrm{k}}$ & $0.17^{\mathrm{j}}$ & $0.38^{\mathrm{k}}$ & $0.27^{\mathrm{det}}$ \\
\hline $\mathrm{I}_{4}$ & $0.18^{\mathrm{c}}$ & $0.29^{\mathrm{c}}$ & $0.53^{\mathrm{c}}$ & $0.40^{\mathrm{c}}$ \\
\hline $\mathrm{I}_{5}$ & $0.12^{\mathrm{h}}$ & $0.23^{\mathrm{f}}$ & $0.41^{\mathrm{j}}$ & $0.33^{\mathrm{cd}}$ \\
\hline $\mathrm{I}_{6}$ & $0.15^{\mathrm{e}}$ & $0.24^{\mathrm{e}}$ & $0.47^{\mathrm{e}}$ & $0.36^{\text {cd }}$ \\
\hline $\mathrm{I}_{7}$ & $0.11^{i}$ & $0.20^{i}$ & $0.42^{i}$ & $0.31^{\text {cde }}$ \\
\hline $\mathrm{I}_{8}$ & $0.14^{\mathrm{f}}$ & $0.22^{\mathrm{g}}$ & $0.43^{\mathrm{h}}$ & $0.30^{\text {cde }}$ \\
\hline $\mathrm{I}_{9}$ & $0.27^{\mathrm{a}}$ & $0.54^{\mathrm{a}}$ & $1.14^{\mathrm{a}}$ & $0.93^{\mathrm{a}}$ \\
\hline $\mathrm{I}_{10}$ & $0.25^{\mathrm{b}}$ & $0.43^{\mathrm{b}}$ & $0.81^{\mathrm{b}}$ & $0.62^{\mathrm{b}}$ \\
\hline$I_{11}$ & $0.13^{\mathrm{g}}$ & $0.21^{\mathrm{h}}$ & $0.28^{\mathrm{m}}$ & $0.19^{\mathrm{f}}$ \\
\hline$I_{12}$ & $0.15^{\mathrm{e}}$ & $0.24^{\mathrm{e}}$ & $0.33^{1}$ & $0.21^{\mathrm{ef}}$ \\
\hline $\mathrm{I}_{13}$ & $0.08^{1}$ & $0.16^{\mathrm{k}}$ & $0.45^{\mathrm{g}}$ & $0.34^{\text {cd }}$ \\
\hline $\mathrm{I}_{14}$ & $0.10^{\mathrm{j}}$ & $0.21^{\mathrm{h}}$ & $0.43^{\mathrm{h}}$ & $0.32^{\mathrm{cd}}$ \\
\hline $\mathrm{I}_{15}$ & $0.14^{\mathrm{f}}$ & $0.25^{\mathrm{d}}$ & $0.47^{\mathrm{f}}$ & $0.35^{\text {cd }}$ \\
\hline Control & 0.02 & 0.03 & 0.05 & 0.04 \\
\hline
\end{tabular}

* Mean of three replications

In a column, means followed by common letters are not significantly different at $5 \%$ level by DMRT 
Table.3 Poly Galacturonase (PG) by different isolates of E. chrysanthemi in Aloe vera

\begin{tabular}{|c|c|c|c|c|}
\hline \multirow{3}{*}{ Isolates } & \multicolumn{4}{|c|}{ Polygalacturonase (percent reduction in viscosity days after inoculation* } \\
\hline & \multicolumn{4}{|c|}{ Days after inoculation(DAI)* } \\
\hline & 2 & 4 & 6 & 8 \\
\hline $\mathrm{I}_{1}$ & $11.40^{\text {cde }}$ & $16.20^{\text {cde }}$ & $28.70^{\mathbf{b c}}$ & $22.40^{\text {cdef }}$ \\
\hline $\mathrm{I}_{2}$ & $10.60^{\text {defg }}$ & $15.40^{\text {cdef }}$ & $26.10^{\mathrm{cd}}$ & $20.30^{\mathrm{fg}}$ \\
\hline $\mathrm{I}_{3}$ & $9.10^{\mathrm{g}}$ & $14.70^{\operatorname{defg}}$ & $23.50^{\mathrm{d}}$ & $19.30^{\mathrm{efg}}$ \\
\hline $\mathrm{I}_{4}$ & $12.70^{\mathrm{c}}$ & $17.10^{\mathrm{c}}$ & $30.00^{\mathrm{b}}$ & $24.20^{c}$ \\
\hline $\mathrm{I}_{5}$ & $10.20^{\operatorname{defg}}$ & $13.80^{\text {efgh }}$ & $27.60^{\mathrm{bc}}$ & $21.50^{\mathrm{def}}$ \\
\hline $\mathrm{I}_{6}$ & $10.70^{\text {def }}$ & $11.90^{\mathrm{h}}$ & $26.90^{\mathrm{bc}}$ & $21.80^{\text {cdef }}$ \\
\hline $\mathrm{I}_{7}$ & $10.30^{\text {cde }}$ & $13.90^{\text {efgh }}$ & $27.20^{\mathrm{bc}}$ & $20.60^{\mathrm{efg}}$ \\
\hline $\mathrm{I}_{8}$ & $10.40^{\operatorname{defg}}$ & $15.00^{\operatorname{defg}}$ & $28.70^{\mathrm{bc}}$ & $23.10^{\text {cdef }}$ \\
\hline $\mathrm{I}_{9}$ & $23.50^{\mathrm{a}}$ & $36.70^{\mathrm{a}}$ & $40.30^{\mathrm{a}}$ & $39.60^{\mathrm{a}}$ \\
\hline $\mathrm{I}_{10}$ & $14.30^{\mathrm{b}}$ & $17.60^{\mathrm{b}}$ & $35.90^{\mathrm{a}}$ & $27.40^{\mathrm{b}}$ \\
\hline $\mathrm{I}_{11}$ & $9.70^{\text {efg }}$ & $13.40^{\text {fgh }}$ & $29.40^{\mathrm{b}}$ & $22.20^{\text {cdef }}$ \\
\hline $\mathrm{I}_{12}$ & $11.50^{\mathrm{cd}}$ & $12.70^{\text {fgh }}$ & $27.20^{\mathrm{bc}}$ & $23.70^{\mathrm{cd}}$ \\
\hline $\mathrm{I}_{13}$ & $10.20^{\text {defg }}$ & $12.60^{\text {fgh }}$ & $26.10^{c}$ & $21.90^{\text {cdef }}$ \\
\hline $\mathrm{I}_{14}$ & $9.80^{\mathrm{efg}}$ & $13.50^{\mathrm{fgh}}$ & $28.00^{\mathrm{bc}}$ & $23.30^{\text {cde }}$ \\
\hline $\mathrm{I}_{15}$ & $9.10^{\mathrm{fg}}$ & $16.10^{\text {cd }}$ & $27.50^{\mathrm{bc}}$ & $23.60^{\mathrm{cd}}$ \\
\hline Control & 0.03 & 0.02 & 0.00 & 0.01 \\
\hline
\end{tabular}

* Mean of three replications

In a column, means followed by common letters are not significantly different at 5\% level by DMRT

Table.4 Pectin Trans Eliminase (PTE) by different isolates of E. chrysanthemi in Aloe vera

\begin{tabular}{|c|c|c|c|c|}
\hline \multirow{3}{*}{ Isolates } & \multicolumn{4}{|c|}{ Pectin trans - eliminase (per cent reduction in viscosity) days after inoculation* } \\
\cline { 2 - 5 } & $\mathbf{4}$ & \multicolumn{4}{|c|}{ Days after inoculation(DAI)* } \\
\cline { 2 - 5 } & $\mathbf{2}$ & $\mathbf{4}$ & $\mathbf{6}$ & $\mathbf{8}$ \\
\hline $\mathrm{I}_{1}$ & $23.40^{\mathrm{h}}$ & $29.70^{\mathrm{1}}$ & $40.60^{\mathrm{k}}$ & 34.20 \\
\hline $\mathrm{I}_{2}$ & $21.20^{\mathrm{j}}$ & $28.90^{\mathrm{o}}$ & $43.10 \mathrm{~g}$ & 33.10 \\
\hline $\mathrm{I}_{3}$ & $24.10^{\mathrm{e}}$ & $30.30^{\mathrm{j}}$ & $41.70^{\mathrm{i}}$ & 34.30 \\
\hline $\mathrm{I}_{4}$ & $29.40^{\mathrm{b}}$ & $33.20^{\mathrm{c}}$ & $44.10^{\mathrm{e}}$ & 38.40 \\
\hline $\mathrm{I}_{5}$ & $26.30^{\mathrm{c}}$ & $31.50^{\mathrm{f}}$ & $40.90^{\mathrm{j}}$ & 36.60 \\
\hline $\mathrm{I}_{6}$ & $23.70^{\mathrm{g}}$ & $32.10^{\mathrm{e}}$ & $42.20^{\mathrm{h}}$ & 32.90 \\
\hline $\mathrm{I}_{7}$ & $16.30^{\mathrm{n}}$ & $29.60^{\mathrm{m}}$ & $45.30^{\mathrm{d}}$ & 36.10 \\
\hline $\mathrm{I}_{8}$ & $23.80^{\mathrm{f}}$ & $30.90^{\mathrm{h}}$ & $49.90^{\mathrm{c}}$ & 35.40 \\
\hline $\mathrm{I}_{9}$ & $33.40^{\mathrm{a}}$ & $46.70^{\mathrm{a}}$ & $64.60^{\mathrm{a}}$ & 56.20 \\
\hline $\mathrm{I}_{10}$ & $17.40^{\mathrm{m}}$ & $34.70^{\mathrm{b}}$ & $53.30^{\mathrm{b}}$ & 45.20 \\
\hline $\mathrm{I}_{11}$ & $22.60^{\mathrm{i}}$ & $30.80^{\mathrm{i}}$ & $40.80^{\mathrm{1}}$ & 36.20 \\
\hline $\mathrm{I}_{12}$ & $18.30^{\mathrm{l}}$ & $31.40^{\mathrm{g}}$ & $43.40^{\mathrm{f}}$ & 32.80 \\
\hline $\mathrm{I}_{13}$ & $15.90^{\mathrm{o}}$ & $30.10^{\mathrm{k}}$ & $40.50^{\mathrm{m}}$ & 30.20 \\
\hline $\mathrm{I}_{14}$ & $19.50^{\mathrm{k}}$ & $29.50^{\mathrm{n}}$ & $42.10^{\mathrm{h}}$ & 33.40 \\
\hline $\mathrm{I}_{15}$ & $25.10^{\mathrm{d}}$ & $32.20^{\mathrm{d}}$ & $39.70^{\mathrm{n}}$ & 37.10 \\
\hline Control & 0.00 & 0.00 & 0.00 & 0.00 \\
\hline
\end{tabular}

* Mean of three replications

In a column, means followed by common letters are not significantly different at 5\% level by DMRT 
Table.5 Changes in content of total sugar in Aloe vera due to infection by different isolates of E. chrysanthemi

\begin{tabular}{|c|c|c|c|c|c|c|}
\hline \multirow{3}{*}{ Isolates } & \multicolumn{3}{|c|}{ Total sugar (mg) } & \multicolumn{2}{c|}{$\begin{array}{c}\text { Per cent increase } \\
\text { over control }\end{array}$} \\
\cline { 2 - 6 } & $\mathbf{2}$ & $\mathbf{4}$ & $\mathbf{6}$ & $\mathbf{8}$ & $\mathbf{2}^{\text {nd }}$ day & $\mathbf{6}^{\text {th }}$ day \\
\cline { 2 - 6 } & $10.60^{\mathrm{g}}$ & $11.60^{\mathrm{i}}$ & $13.80^{\mathrm{h}}$ & $12.80^{\mathrm{g}}$ & 7.07 & 39.39 \\
\hline $\mathrm{I}_{1}$ & $10.90^{\mathrm{e}}$ & $11.80^{\mathrm{g}}$ & $13.90^{\mathrm{g}}$ & $13.20^{\mathrm{f}}$ & 10.10 & 40.40 \\
\hline $\mathrm{I}_{2}$ & $10.80^{\mathrm{f}}$ & $11.40^{\mathrm{k}}$ & $13.30^{\mathrm{k}}$ & $12.40^{\mathrm{j}}$ & 9.09 & 34.34 \\
\hline $\mathrm{I}_{3}$ & $10.20^{\mathrm{i}}$ & $12.20^{\mathrm{d}}$ & $14.40^{\mathrm{c}}$ & $13.20^{\mathrm{f}}$ & 3.03 & 45.45 \\
\hline $\mathrm{I}_{4}$ & $10.80^{\mathrm{f}}$ & $11.50^{\mathrm{j}}$ & $14.10^{\mathrm{f}}$ & $13.30^{\mathrm{e}}$ & 9.09 & 42.42 \\
\hline $\mathrm{I}_{5}$ & $11.40^{\mathrm{h}}$ & $12.10^{\mathrm{e}}$ & $14.30^{\mathrm{d}}$ & $13.30^{\mathrm{e}}$ & 15.15 & 44.44 \\
\hline $\mathrm{I}_{6}$ & $10.90^{\mathrm{e}}$ & $11.60^{\mathrm{i}}$ & $13.80^{\mathrm{h}}$ & $12.60^{\mathrm{i}}$ & 10.10 & 39.39 \\
\hline $\mathrm{I}_{7}$ & $10.80^{\mathrm{f}}$ & $11.90^{\mathrm{f}}$ & $13.90^{\mathrm{g}}$ & $12.70^{\mathrm{h}}$ & 9.09 & 40.40 \\
\hline $\mathrm{I}_{8}$ & $11.50^{\mathrm{a}}$ & $12.60^{\mathrm{a}}$ & $14.60^{\mathrm{a}}$ & $13.70^{\mathrm{a}}$ & 16.16 & 47.47 \\
\hline $\mathrm{I}_{9}$ & $11.30^{\mathrm{b}}$ & $12.50^{\mathrm{b}}$ & $14.50^{\mathrm{b}}$ & $13.60^{\mathrm{b}}$ & 14.14 & 46.46 \\
\hline $\mathrm{I}_{10}$ & $11.00^{\mathrm{d}}$ & $12.20^{\mathrm{a}}$ & $13.30^{\mathrm{k}}$ & $13.40^{\mathrm{d}}$ & 11.11 & 34.34 \\
\hline $\mathrm{I}_{11}$ & $10.60^{\mathrm{g}}$ & $11.70^{\mathrm{h}}$ & $13.70^{\mathrm{i}}$ & $12.80^{\mathrm{g}}$ & 7.07 & 38.38 \\
\hline $\mathrm{I}_{12}$ & $11.20^{\mathrm{c}}$ & $11.10^{\mathrm{l}}$ & $13.20^{\mathrm{l}}$ & $12.30^{\mathrm{k}}$ & 13.13 & 33.33 \\
\hline $\mathrm{I}_{13}$ & $11.30^{\mathrm{b}}$ & $12.30^{\mathrm{c}}$ & $14.20^{\mathrm{e}}$ & $13.50^{\mathrm{c}}$ & 14,14 & 43.43 \\
\hline $\mathrm{I}_{14}$ & $10.80^{\mathrm{f}}$ & $12.30^{\mathrm{c}}$ & $13.60^{\mathrm{j}}$ & $13.40^{\mathrm{d}}$ & 9.09 & 37.37 \\
\hline $\mathrm{I}_{15}$ & 9.90 & 9.90 & 9.90 & 9.90 & - & - \\
\hline Control & \multicolumn{3}{|c|}{} & & & \\
\hline
\end{tabular}

* Mean of three replications

In a column, means followed by common letters are not significantly different at 5\% level by DMRT

Table.6 Changes in content of reducing sugars in Aloe vera due to infection by different isolates of E. chrysanthemi

\begin{tabular}{|c|c|c|c|c|c|c|}
\hline \multirow{3}{*}{ Isolates } & \multicolumn{3}{|c|}{ Reducing sugars (mg) } & \multicolumn{2}{c|}{$\begin{array}{c}\text { Per cent increase } \\
\text { over control }\end{array}$} \\
\cline { 2 - 6 } & $\mathbf{2}$ & $\mathbf{4}$ & $\mathbf{6}$ & $\mathbf{8}$ & $\mathbf{2}^{\text {nd }}$ day & $\mathbf{6}^{\text {th }}$ day \\
\cline { 2 - 6 } & $2.90^{\mathrm{f}}$ & $4.90^{\mathrm{h}}$ & $5.70^{\mathrm{h}}$ & $5.60^{\mathrm{h}}$ & 11.53 & 62.85 \\
\hline $\mathrm{I}_{1}$ & $3.00^{\mathrm{e}}$ & $5.10^{\mathrm{f}}$ & $6.20^{\mathrm{c}}$ & $6.10^{\mathrm{c}}$ & 15.38 & 77.14 \\
\hline $\mathrm{I}_{2}$ & $2.30^{\mathrm{i}}$ & $5.00^{\mathrm{g}}$ & $6.20^{\mathrm{c}}$ & $6.10^{\mathrm{c}}$ & 7.69 & 77.14 \\
\hline $\mathrm{I}_{3}$ & $3.20^{\mathrm{c}}$ & $4.80^{\mathrm{i}}$ & $5.90^{\mathrm{i}}$ & $5.70^{\mathrm{g}}$ & 23.07 & 68.57 \\
\hline $\mathrm{I}_{4}$ & $2.80^{\mathrm{g}}$ & $4.90^{\mathrm{h}}$ & $6.50^{\mathrm{d}}$ & $5.30^{\mathrm{j}}$ & 7.69 & 80.00 \\
\hline $\mathrm{I}_{5}$ & $3.10^{\mathrm{d}}$ & $4.70^{\mathrm{j}}$ & $6.00^{\mathrm{c}}$ & $5.70^{\mathrm{g}}$ & 19.23 & 71.42 \\
\hline $\mathrm{I}_{6}$ & $3.20^{\mathrm{c}}$ & $5.10^{\mathrm{f}}$ & $5.60^{\mathrm{k}}$ & $5.50^{\mathrm{i}}$ & 23.07 & 60.00 \\
\hline $\mathrm{I}_{7}$ & $3.00^{\mathrm{e}}$ & $4.80^{\mathrm{i}}$ & $6.10^{\mathrm{g}}$ & $5.80^{\mathrm{f}}$ & 15.38 & 74.28 \\
\hline $\mathrm{I}_{8}$ & $3.40^{\mathrm{a}}$ & $5.90^{\mathrm{a}}$ & $6.60^{\mathrm{a}}$ & $6.40^{\mathrm{a}}$ & 30.76 & 88.57 \\
\hline $\mathrm{I}_{9}$ & $3.30^{\mathrm{b}}$ & $5.80^{\mathrm{b}}$ & $6.30^{\mathrm{b}}$ & $6.20^{\mathrm{b}}$ & 26.92 & 85.71 \\
\hline $\mathrm{I}_{10}$ & $2.40^{\mathrm{h}}$ & $4.60^{\mathrm{k}}$ & $6.20^{\mathrm{f}}$ & $6.10^{\mathrm{c}}$ & 11.54 & 77.14 \\
\hline $\mathrm{I}_{11}$ & $3.10^{\mathrm{d}}$ & $5.70^{\mathrm{c}}$ & $6.20^{\mathrm{c}}$ & $6.00^{\mathrm{d}}$ & 19.23 & 77.14 \\
\hline $\mathrm{I}_{12}$ & $2.70^{\mathrm{g}}$ & $5.60^{\mathrm{d}}$ & $5.80^{\mathrm{j}}$ & $5.60^{\mathrm{e}}$ & 3.85 & 65.71 \\
\hline $\mathrm{I}_{13}$ & $2.90^{\mathrm{e}}$ & $5.70^{\mathrm{c}}$ & $6.10^{\mathrm{d}}$ & $5.90^{\mathrm{e}}$ & 11.54 & 74.28 \\
\hline $\mathrm{I}_{14}$ & $3.20^{\mathrm{d}}$ & $5.50^{\mathrm{e}}$ & $6.00^{\mathrm{e}}$ & $5.80^{\mathrm{f}}$ & 23.07 & 71.42 \\
\hline $\mathrm{I}_{15}$ & 2.60 & 3.00 & 3.50 & 4.00 & - & - \\
\hline Control $^{\mathrm{y}}$ & 2.60 & & & & \\
\hline
\end{tabular}

* Mean of three replications

In a column, means followed by common letters are not significantly different at $5 \%$ level by DMRT 
Table.7 Changes in content of non-reducing sugars in Aloe vera due to infection of different isolates of $E$. chrysanthemi

\begin{tabular}{|c|c|c|c|c|c|c|}
\hline \multirow{3}{*}{ Isolates } & \multicolumn{4}{|c|}{ Non reducing sugars (mg) } & \multirow{2}{*}{\multicolumn{2}{|c|}{$\begin{array}{l}\text { Per cent increase } \\
\text { over control }\end{array}$}} \\
\hline & \multicolumn{4}{|c|}{ Days after inoculation(DAI)* } & & \\
\hline & 2 & 4 & 6 & 8 & $2^{\text {nd }}$ day & $8^{\text {th }}$ day \\
\hline $\mathrm{I}_{1}$ & $7.60^{\mathrm{i}}$ & $6.00^{\mathrm{h}}$ & $6.30^{\mathrm{g}}$ & $5.40^{\mathrm{i}}$ & 10.14 & 5.88 \\
\hline $\mathrm{I}_{2}$ & $8.30^{\mathrm{c}}$ & $6.40^{\mathrm{d}}$ & $6.10^{j}$ & $5.50^{\mathrm{h}}$ & 20.2 & 7.84 \\
\hline $\mathrm{I}_{3}$ & $6.60^{\mathrm{n}}$ & $6.20^{\mathrm{f}}$ & $6.70^{c}$ & $6.10^{\mathrm{e}}$ & 21.73 & 19.60 \\
\hline $\mathrm{I}_{4}$ & $8.20^{\mathrm{d}}$ & $6.10^{\mathrm{g}}$ & $6.80^{\mathrm{b}}$ & $6.30^{c}$ & 18.84 & 23.52 \\
\hline $\mathrm{I}_{5}$ & $7.10^{\mathrm{m}}$ & $6.40^{\mathrm{d}}$ & $6.50^{\mathrm{e}}$ & $5.30^{\mathrm{j}}$ & 2.89 & 3.92 \\
\hline $\mathrm{I}_{6}$ & $7.80^{\mathrm{g}}$ & $6.30^{\mathrm{e}}$ & $6.70^{c}$ & $5.90^{\mathrm{f}}$ & 13.04 & 15.68 \\
\hline $\mathrm{I}_{7}$ & $8.10^{\mathrm{e}}$ & $6.50^{c}$ & $6.30^{\mathrm{g}}$ & $5.90^{\mathrm{f}}$ & 17.39 & 15.68 \\
\hline $\mathrm{I}_{8}$ & $7.50^{\mathrm{j}}$ & $6.10^{\mathrm{g}}$ & $6.20^{\mathrm{h}}$ & $5.50^{\mathrm{h}}$ & 8.69 & 7.64 \\
\hline $\mathrm{I}_{9}$ & $9.20^{\mathrm{a}}$ & $6.80^{\mathrm{a}}$ & $6.90^{\mathrm{a}}$ & $6.50^{\mathrm{a}}$ & 33.33 & 27.45 \\
\hline $\mathrm{I}_{10}$ & $8.70^{\mathrm{b}}$ & $6.70^{\mathrm{b}}$ & $6.80^{b}$ & $6.40^{\mathrm{b}}$ & 26.08 & 25.49 \\
\hline $\mathrm{I}_{11}$ & $8.00^{\mathrm{f}}$ & $6.20^{\mathrm{f}}$ & $6.60^{\mathrm{d}}$ & $5.70^{\mathrm{g}}$ & 15.94 & 11.76 \\
\hline $\mathrm{I}_{12}$ & $7.70^{\mathrm{h}}$ & $6.10^{\mathrm{g}}$ & $6.20^{\mathrm{h}}$ & $5.50^{\mathrm{h}}$ & 11.59 & 7.84 \\
\hline $\mathrm{I}_{13}$ & $7.20^{1}$ & $6.20^{\mathrm{f}}$ & $6.40^{\mathrm{f}}$ & $5.70^{g}$ & 4.35 & 11.76 \\
\hline $\mathrm{I}_{14}$ & $8.00^{\mathrm{f}}$ & $6.40^{\mathrm{d}}$ & $6.10^{\mathrm{j}}$ & $6.20^{\mathrm{d}}$ & 15.94 & 21.56 \\
\hline $\mathrm{I}_{15}$ & $7.30^{\mathrm{k}}$ & $6.50^{c}$ & $6.30^{\mathrm{g}}$ & $6.10^{\mathrm{e}}$ & 5.79 & 19.60 \\
\hline Control & $6.90^{\mathrm{n}}$ & $5.90^{\mathrm{i}}$ & $5.80^{\mathrm{k}}$ & $5.10^{\mathrm{k}}$ & & \\
\hline
\end{tabular}

* Mean of three replications

In a column, means followed by common letters are not significantly different at $5 \%$ level by DMRT

Changes in content of reducing sugars in Aloe vera due to infection by different isolates of $E$. chrysanthemi

The reducing sugar content showed significant increase in the inoculated leaves as compared to control. In this respect of the 15 isolates varied from 60.00 to 88.57 percent increase six DAI (Table 6). The increase was the $(88.57 \%)$ maximum in Aloe vera plants inoculated with Melur isolate $\left(\mathrm{I}_{9}\right)$ followed by Palamadu isolate $\left(\mathrm{I}_{10}\right)$ recording 85.71 per cent increase. All the isolates showed increase in reducing sugar content six DAI which ranged from 5.60 to 6.60 per cent. The increase was the minimum in the case of $\mathrm{I}_{7}$
(Nagerkoil) which recorded only 60.00 per cent increase over control (Table 6).

Changes in content of non-reducing sugars in Aloe vera due to infection by different isolates of $E$. chrysanthemi

The effect of bacterial infection on nonreducing sugar content of Aloe vera plants was studied and the results are presented in table 7 . The results revealed that the nonreducing sugar content inoculated of aloe plants increased from the two DAI till the six DAI. All the 15 isolates recorded in the reducing sugar content ranging from 3.92 to 27.45 percent increase six DAI. The 
maximum increase of 27.45 per cent was observed in two DAI Melur ( $\left.\mathrm{I}_{9}\right)$ isolate followed by Palamadu $\left(\mathrm{I}_{10}\right)$ isolate with 25.49 per cent increase over control. All the isolates recorded increase reducing sugar content six DAI ranged from 5.30 to 6.50 per cent. The increase was the in minimum $(3.92 \%)$ in aloe plants inoculated with isolate $\mathrm{I}_{5}$ (Table 7 ).

The above results revealed that the contents of total sugars and reducing sugars significantly increased due to the inoculation of all the 15 isolates of the pathogen, while the nonreducing sugar content showed a reverse trend. The increase in sugar might be due to the conversion of complex carbohydrates to simple forms during pathogenesis by various enzymes (Fladung and Gieffers, 1983). The increase in sugar might be due to the conversion of complex carbohydrates to simple forms during pathogenesis by various enzymes. Fladung and Gieffers (1983) also made similar observations in infection of Erwinia carotovora sub sp atroseptica, Alternaria alternata and Botrytis cinerea of potato tubers. Similarly in cassava, increase in sugar content occurred due to infection by Phytophthora sp (Johnson, 1998). Prabhakar (1999) reported an increase in total and reducing sugar content in the peel and pulp of mango fruits inoculated with $C$. gleosporoides.

The degradation of complex polymers of carbohydrates to simple one is brought about by the production of various pectic and pectolylic enzymes produced by $E$. carotovora subsp. carotovora. Pectolytic microorganisms or cell free pectic enzymes are responsible for tissue maceration as observed by Chesson (1980).

The present investigation revealed the production of polygalacturanase, pectin methyl esterase, pectin trans eliminase and pectate lyase in the aloe plants inoculated with E. chrysanthemi. Dasgupta and Mandal (1989) found that E. carotovora subsp. carotovora produced pectolytic enzymes which degraded the cell wall. The production of extra cellular endo polygalacturanase and endo pectin trans eliminases by E. carotovora subsp. carotovora inhibiting soft rot of banana was reported by Raj Kumar (2006). Perombelon and Kelman (1980) reported the main distinguishing feature of soft rot Erwinia from other Erwinia sp. was its ability to produce large quantity of pectic enzymes that enable them to macerate parenchymatous tissues of a wide range of plants.

\section{References}

Anselm, A., 2004. Nature power. $3^{\text {rd }}$ edn. Fr. Anselm Adodo, SB Ewu-Esan, Nigeria, pp. 288.

Blumenthal and Mark. 2002. Herbal gram. America Botanical Council, Austin, T. 49: $52-53$.

Chesson, A. 1980. Role of pectolytic microorganisms in relation to tissue maceration during postharvest handling. J. Appl. Bacteriol., 48: 1-45.

Dasgupta, M.K. and Mandal, N.C. 1989. Postharvest Pathology of Perishables. Oxford and IBH Publishing Co. Pvt. Ltd., New Delhi, pp388.

Davis, R. H., M G. Leithner, J. M. Russo and M. E. Bryne, 2000. Advance methods in plant breeding and biotechnology. $J$. Am. Ped., 79: 559-562.

Fladung, M. and Gieffers, W. 1983. Resistance reactions of leaves and tubers of transgenic tetraploid potato to bacterial and fungal pathogen. Correlation with sugar, starch and chlorophyll content. Physiol. Mol. Plant Pathol., 42: 123-132.

Hect, A. 1981. The overselling of aloe vera. FDA Consumer, 15: 26-29.

Hedge, J.E. and Hofrieter, B.T. 1962. In: Methods in carbohydrate chemistry. 
Vol. 17. R.L. Whistler and J.N. Be Miller (Eds.) Academic Press. New York. p420.

Laurant, P., Buchon, J.F., Michel, G., and orange, N. 2000. Production of pectate lyases and cellulases by Chryseomonas luteola MFCLO depends on the growth temperature and the native culture medium: Evidence for two critical temperatures. Appl. Environ. Microbiol., 68(4): 1538-1543.

Mahadevan, A. and Sridar, R. 1982. Methods in Physiological Plant Pathology. Shivakami Publications, $21^{\text {st }}$ Ed., Madras, India. pp. 316.

Parthiban, V. K. 2004. Studies on the bacterial soft rot of carrot caused by Erwinia carotovora var. Carotovora (Jones) Ph.D. Thesis. Tamil Nadu Agricultural University, Coimbatore. p. 114.

Pirhonen, M., Flego, D., Heikinheimo, R., and Palva, E.T. 1993. A small diffusible signal molecule is responsible for the global control of virulence and exoenzyme production in plant pathogen Erwinia carotovora. EMBO J. 12: 2467-2476.

Prabakar, K. 1999. Anthracnose disease of mango fruits caused by Colletotrichum gloeosporioides Penz. Ph.D. thesis. Tamil Nadu Agric. Univ., Coimbatore, Tamil Nadu, India. p196.

Rajkumar, 2006. Molecular and biochemical approaches for the selection of biocontrol agents for the eco-friendly management of rhizome rot of banana caused by Erwinia carotovora sub sp. Carotovora. Ph.D. Thesis. Tamil Nadu Agricultural University, Coimbatore. pp. 107-119.

Raupach, G.S. and Kloepper, J.W. 1998. Mixtures of plant growth promoting rhizobacteria to enhance biological control of multiple cucumber pathogens. Phytopathology, 88: 11581164.

Robert, B. and Hentry, T. 2004. Medicinal Plantsa. Asiatic Publishing House, New Delhi, 308 p.

Sendhilvel, V. 2000. Studies on the bacterial soft rot of onion bulbs caused by $E$. carotovora (Jones). M.Sc. thesis. Tamil Nadu Agric. Univ., Coimbatore, Tamil Nadu, India. p133.

Sofowora, A. 1984. Medicinal plants and traditional medicines in Africa, Johan Wiley and Sons Ltd., New York, pp. 256.

Somogyi, M. 1952. Notes on sugar estimation. J. Biol. Chem., 200: 245.

Swaminathan, M. S. and S. L. Kochhar, 1992. Comparative petiole anatomy as an aid to the classification of Africa Genius. $\mathrm{CAB}$ International Wallingford, $\mathrm{pp}$. 409.

Tyler, V., 1994. Herbs of choice, the therapeutical use of phyto- medicinals. Binghamton NY: Pharmaceutical products.

\section{How to cite this article:}

Syamala, M. and Ciba, C. 2017. In vitro Inhibition of Pectolytic Enzymes of Erwinia chrysanthemi by Combined Application of Pseudomonas fluorescens and Bacillus subtilis on Aloe vera. Int.J.Curr.Microbiol.App.Sci. 6(12): 574-584.

doi: https://doi.org/10.20546/ijcmas.2017.612.070 